\title{
Academic Achievement Through FLES: A Case for Promoting Greater Access to Foreign Language Study Among Young Learners
}

\author{
CAROLYN TAYLOR \\ University of Wyoming \\ Secondary Education \\ 201 McWhinnie Hall \\ Laramie, WY 82071 \\ Email: ctaylor@uwyo.edu
}

\author{
ROBERT LAFAYETTE \\ Louisiana State University \\ Curriculum and Instruction \\ Baton Rouge, LA 70803 \\ Email: rlafaye@lsu.edu
}

\begin{abstract}
The No Child Left Behind Act of 2001 established foreign languages as a core curricular content area; however, instructional emphasis continues to be placed on curricular areas that factor into state educational accountability programs. The present study explored whether foreign language study of first-year Grade 3 foreign language students who continued their foreign language study through Grade 5 in Louisiana public schools contributed to their academic achievement in curricular areas tested on the Iowa Tests of Basic Skills (ITBS) and the Louisiana Educational Assessment Program for the 21st Century (LEAP 21) test. Notable findings emerged. First, foreign language (FL) students significantly outperformed their nonFL peers on every test (English language arts, mathematics, science, and social studies) of the Grade 4 LEAP 21. Second, the present research suggested that regardless of the test, whether the Grade 4 criterion-referenced LEAP 21 or the Grade 5 norm-referenced ITBS, at each grade level FL students significantly outperformed their non-FL counterparts on language achievement tests.
\end{abstract}

TITLE IX, PART A, SECTION 9101 OF THE CURRENT federal educational legislation, the No Child Left Behind Act of 2001 (NCLB), designates foreign languages as part of the core curriculum, along with English language arts, math, science, civics and government, economics, arts, history, and geography content areas. Federal funding is provided for foreign language study through the Foreign Language Assistance Act of 2001, which is Title V, Part D, Subpart 9 of NCLB. Although foreign languages are designated as part of the core content area under NCLB, educational policy makers at the state and local levels often opt to place greater instructional emphasis on content areas in which students, and ultimately the school systems themselves, are held accountable through

The Modern Language Journal, 94, i, (2010) 0026-7902/10/22-42 \$1.50/0

(C)2010 The Modern Language Journal testing. As a result, curricular areas such as foreign languages and the arts in schools across America often take a backseat to curricular areas that factor into state accountability assessments-namely, English language arts, math, and, more recently, science.

\section{REVIEW OF THE LITERATURE}

\section{Elementary Foreign Language Study and Academic Achievement}

Foreign Language in the Elementary Schools (FLES) programs were implemented in elementary schools in the United States as a result of funding through the National Defense Education Act of 1958, which was spurred on by Russian advances in technology during the Sputnik era. In this context, foreign language (FL) study was perceived as vital to the interest and promotion of 
American national security. As such, it received a great deal of attention and financial support for its integration into the American educational curriculum. Empirical research on FL study and student achievement has been carried out since the late 1950s, at a time when FLES programs were taking root across America.

Research on Early FLES Programs. The principal aim of early FLES and academic achievement research was to investigate whether allocating time for elementary FL study had any negative effects on student achievement in other academic areas. Early FLES research by and large found that making time for FL instruction in the elementary curriculum had no adverse effects on academic achievement among student participants. Studies conducted by Lopato (1963), Johnson, Ellison, and Flores (1961), Johnson, Flores, and Ellison (1963), and Leino and Haak (1963) comparing the academic achievement of students participating in FL instruction versus their nonparticipatory peers concluded that FL student participants demonstrated no significant loss in achievement in other curricular areas. More comprehensive findings of subsequent research on FLES and academic achievement now will be examined.

Research on FLES Programs from the 1980s to 2005. Research on FLES and academic achievement conducted in recent decades has broadened the scope of investigation of student academic achievement in a wider variety of content areas. In addition, these studies have examined the academic achievement of students who learn languages through more contemporary elementary FL teaching methods and approaches.

A study conducted by Armstrong and Rogers (1997) used standardized pretests and posttests of reading comprehension, language, and math measures to examine the performance of 100 third graders in two Pittsburgh, Kansas city schools. These students received 30 minutes of Spanish instruction 3 days per week that heavily incorporated the Total Physical Response teaching method and were compared to students not receiving Spanish instruction. They found that the FL treatment group demonstrated significant differences in basic skills achievement among math and language scores over their non-FL counterparts.

DiPietro (1980) investigated FL study and academic achievement among Arlington, Virginia children participating in content-based FL programs in Grades 1 through 6. Student data were collected on attendance, report card grades, ratings of academic performance by regular classroom teachers, and scores on standardized reading and math tests both before and after participation in the 14-week FL study program. The FL instruction reinforced concepts students were learning in math and social studies classes and explored the customs, history, and artistic backdrop of the target cultures of the languages studied. Results showed that children's reading ability exhibited marked improvement upon completion of the 14 weeks of FL exposure.

Garfinkel and Tabor (1991) conducted a study comparing the English reading scores of Grade 6 children who had begun their study of Spanish as third or fourth graders in an FLES program and either did or did not extend their study of Spanish for 1 or 2 years into Grades 5 and 6. Findings showed that there was no significant difference between groups that did and did not continue their study of Spanish. However, when further classifying students in each group according to their ability level (low, medium, or high), based on the results of their School Ability Index of the OtisLennon School Ability Test, students performing within the low-ability group who continued their study of Spanish significantly outperformed lowability students who did not extend their study of Spanish on reading achievement measures. Thus, the findings support sustained FL study, especially for low-ability students, as there is a positive correlation between extended FL study and improved reading scores among children of low ability. This finding stands in contrast with Lopato's (1963) position nearly 30 years prior to the 1991 Garfinkel and Tabor study.

Rafferty (1986) compared the 1985 Louisiana Basic Skills Test scores of Louisiana FLES students who had participated in second language study in Grades 3, 4, and 5 to those of their non-FLES peers. The study matched treatment and control groups for race, sex, and grade level and controlled for differences in academic achievement among FLES and non-FLES participants by using scores on the 1984 Louisiana Basic Skills Tests of math and language arts as covariates. To form the treatment and control groups, 13,200 participants were randomly selected from a population of students who had no FL exposure at home, were fluent in English, and had not repeated a grade in 1985. All Grade 3, 4, and 5 FLES students, despite race, sex, or academic level, scored higher on the language arts portions of the Louisiana Basic Skills Tests than did their non-FLES peers. With regard to participant achievement on math portions of the Basic Skills Tests, FLES groups showed neither a significant advantage nor a 
significant disadvantage. By Grade 5, FLES students' math scores were higher than those of non-FLES participants, although not statistically significantly so.

A more recent Louisiana study conducted by Lang (1990) explores the relationship of FLES study on English language achievement on the norm-referenced California Achievement Tests. Lang compared FLES and non-FLES groups functioning on or below grade level at Grades 4, 6, and 9 to determine whether students with various lengths of FL exposure (none, 1 year, 3 years, or 5 years) would perform differently on tests of English language skills. Note that the determination of whether students were performing on or below grade level was made and reported by their teachers. Students were matched according to reading level, socioeconomic status, the length of participation in FL study, and whether they qualified for participation in remediation programs. The results showed that FLES students scored significantly higher in English language arts and reading tests at Grades 4, 6, and 9 compared to non-FLES students, regardless of whether they were functioning at or below grade level.

In concert with Armstrong and Rogers (1997) and Rafferty (1986), Saunders (1998) examined whether Grade 3 FLES students would fare better than their monolingual peers on verbal and mathematical standardized test measures. Saunders found that FLES students participating in the FL content-related Georgia Elementary School Foreign Language Model Program performed significantly higher on Iowa Tests of Basic Skills (ITBS) math measures. Although ITBS reading measures of the treatment group surpassed those of their non-FLES peers, they were not statistically significant.

Schuster (2005) compared the academic achievement of sixth graders who had participated in a pilot FLES program beginning in Grade 2 and continued in the program through Grade 5 to their non-FLES counterparts on reading total, language total, math total, and core total ITBS measures administered in Grade 6. To control for differences among group performance, the Grade 2 ITBS core battery scores of students in both the control and treatment groups were used as covariates. The findings indicated that there were no significant differences between the performance of treatment and control groups on the Grade 6 ITBS core battery subtests. It is worth considering that perhaps the treatment group's limited exposure to the target language ( 1 hour of FL instruction per week) was not significant enough to make an appreciable contribution to their academic achievement in other curricular areas.

Whereas prior research, with the exception of Schuster (2005), primarily examines the relationship between FLES study and academic achievement on verbal and mathematical measures, the present study seeks to broaden the scope of investigation to include Louisiana FLES students' achievement not only in English and math but also in the disciplines of social studies and science.

\section{MATERIALS AND METHODS}

The purpose of the present study is to discern the effects of the study of FL in Louisiana FLES programs on student achievement on standardized reading, language, math, social studies, and science measures.

\section{Research Questions Investigating Student Comparison Scores}

The present study asks the six following quantitative research questions requiring statistical analyses. These questions pertain to students' performance in academic areas in which they are tested by means of state standardized tests.

Research Question 1. Do Grade 3 students participating in the Louisiana Foreign Language Elementary School program for the first year have significantly higher scores than their non-FL peers on the ITBS, which includes the combination of reading, language, math, science, and social studies subtest scores?

Research Question 2. Do Grade 4 students participating in the Louisiana Foreign Language Elementary School program for the second year have significantly higher scores than their nonFL peers on the Louisiana Educational Assessment Program for the 21st Century (LEAP 21), which includes the combination of English language arts, math, science, and social studies subtest scores?

Research Question 3. Do Grade 5 students participating in the Louisiana Foreign Language Elementary School program for the third year have significantly higher scores than their non-FL peers on the ITBS, which includes the combination of reading, language, math, social studies, and science subtests?

Research Question 4. After adjusting for prior performance on the Grade 3 ITBS, do Grade 
4 students after 2 years of participation in the Louisiana Foreign Language Elementary School program make significantly greater academic gains on the combination of Grade 4 LEAP 21 subtest scores than their non-FL peers?

Research Question 5. After adjusting for prior performance on the Grade 4 LEAP 21, do Grade 5 students after 3 years of participation in the Louisiana Foreign Language Elementary School program make significantly greater academic gains on the combination of Grade 5 ITBS subtest scores than their non-FL peers after they progress from Grade 4 to Grade 5?

Research Question 6. After adjusting for prior performance on the Grade 3 ITBS, do Grade 5 students after 3 years of participation in the Louisiana Foreign Language Elementary School program make significantly greater academic gains on the combination of Grade 5 ITBS subtest scores than their non-FL peers after participating in the program from Grade 3 to Grade 5?

\section{Participants}

For the purposes of the present research, the treatment and control groups were derived through the nonprobability means of purposive sampling. It is important to note that in 1984 the Louisiana State Board of Elementary and Secondary Education (BESE) mandated that FL instruction be required for all academically able students in Grades 4 through 8 and be optional for all other students. The term academically able is operationally defined as students functioning on grade level in reading as determined by the school district. All FL classes in Grades 4 through 8 must meet for a minimum of 30 minutes daily and 150 minutes per week in Grades 7 and 8.

Treatment Group Profile. The treatment group consists of all students who were in Grade 3 during the 1999-2000 school year $(n=1,050)$, in Grade 4 during the 2000-2001 school year $(n=$ 849 ), in Grade 5 during the 2001-2002 school year $(n=609)$ and who, during this 3-year period, were enrolled in Louisiana public schools offering FLES-type programs commencing in Grade 3 and continuing through at least Grade 5.

The total number of schools with this program grade configuration is 16 . Of the 16 schools offering FL study beginning in Grade 3 (prior to the BESE-mandated fourth-grade level), 8 offered French and 8 offered Spanish. The present research examined the academic performance on standardized test measures of these children as third graders, those who remained enrolled in the program as fourth graders in 2001-2002, and then those who continued program participation as fifth graders in 1999-2002. Although the present study employed purposive sampling of intact groups in identifying the treatment and control groups, student-level data were used to compare achievement of students in these groups at and between grade levels.

To select the treatment groups, it was necessary to determine in which Louisiana schools FLEStype FL instruction begins in Grade 3 and continues through and including at least Grade 5. Once the schools were identified, we organized them by parish and then by educational region. By process of elimination, we were able to identify all schools not offering FL programs within parishes comprising the treatment group. Note that schools whose students learn FL in immersion settings are not included in the treatment group, as their language learning environment differs markedly from that of the FLES model.

Control Group Profile. The control group is made up of students in Louisiana public elementary schools not offering an FL within parishes that do offer FL in some public elementary schools, with the exception of Lafourche, St. John the Baptist, and Acadia parishes. All elementary schools in these three parishes have FL programs. Therefore, treatment group schools in these parishes were matched to schools in adjacent parishes within the regions in which they are located. The control group students were in Grade 3 during the 1999-2000 school year $(n=802)$, in Grade 4 during the 2000-2001 school year $(n=636)$, and in Grade 5 during the 2001-2002 school year $(n=399)$.

Students in the schools comprising the treatment and control groups were matched with regard to several factors. First was the socioeconomic status of the schools' student body, as evidenced by the number of students eligible for free or reduced lunch. The mean percentage of treatment group students eligible for free and reduced lunch was $70.9 \%$, and the mean percentage of control group students eligible for free and reduced lunch was $73.7 \%$. The second was the schools' locality, or its location within a given region. Louisiana is divided into eight geographical/educational regions composed of 514 parishes per region (see the Appendix). The third factor was the schools' total enrollment figures. The final factor was the schools' urbanicitythe extent to which a geographical area is urban. 
Schools were categorized as urban, suburban, or rural for purposes of matching.

Given the fact that students in both the treatment and control groups have taken three standardized tests by the time they are in Grade 5 (ITBS as third graders in 2000, LEAP as fourth graders in 2001, and ITBS as fifth graders in 2002), we were able to examine a fairly broad scope of the effect of FL study on individual student academic achievement in other subject areas. This 3-year window of investigation also allowed any potential difference in outcomes on broad-based academic achievement to be evidenced as students in the treatment group were exposed to subsequent years of FL study.

\section{Research Design}

Comparison of Student Test Scores. The present research design is causal-comparative, because the schools comprising the control and treatment groups were already intact and are matched on specific criteria rather than being randomly selected and matched. It is vital that both control and treatment groups be as similar as possible, so as to minimize the risk that differences in performance on the ITBS and LEAP 21 tests could be attributed to differences among group characteristics, thereby increasing the validity of the study.

Description of Standardized Test Instruments. The following is a description of the ITBS and LEAP 21 tests. In addition, an explanation of how these scores are reported is provided.

The ITBS is made up of norm-referenced achievement tests published by Riverside Publishing of Itasca, Illinois. The format of the ITBS consists entirely of multiple-choice items. The scores are nationally standardized, which allows for the comparison of local student performance to students who are tested in a national sample. The ITBS results are reported at the state and district levels using student standard scores, percentile ranks, stanines, and normal curve equivalents. Louisiana students in Grades 3, 5, 6, and 7 take the ITBS in the spring. The ITBS encompass the following areas: Reading (vocabulary and reading comprehension); language (spelling, capitalization, punctuation, usage, and expression); mathematics (concepts, estimation, problem solving, and data interpretation with computation tested in Grade 3 only); social studies (history, economics, geography, and government and society); science (scientific inquiry, life science, earth and space science, and physical science); and sources of information (maps and diagrams, and reference materials).

The LEAP 21 is a criterion-referenced test given to Louisiana students to gauge how well they have mastered Louisiana content standards in the areas of English language arts, mathematics, science, and social studies. The format of the LEAP 21 test includes multiple-choice items as well as constructed responses in the form of short-answer, extended-response, and essay items. The LEAP 21 is administered to Louisiana students in the spring in Grades 4 and 8. Students' test results are reported as scaled scores ranging from 100 to 500 in each subject area, placing them at one of the following achievement levels: Advanced, Proficient, Basic, Approaching Basic, or Unsatisfactory. Students at the fourth- and eighth-grade levels must score in the Approaching Basic category or above in both the English language arts and mathematics tests in order to be promoted to the next grade level. As indicated in Table 1, the scaled score ranges for Grade 4 students according to achievement level are presented as indicated in the 20002001 Louisiana Interpretive Guide (Louisiana Department of Education, 2001). The results, in addition to being reported on individual students, are also reported on district and state test performance.

Table 2 compares the skills and subject areas tested on the LEAP 21 and ITBS tests. The difference between the LEAP 21 and ITBS language measures lies in the assessment of writing. Whereas the LEAP 21 tests students' ability to write competently, the ITBS does not contain a writing portion. With regard to mathematics, the areas tested are quite similar; however, the LEAP 21 additionally assesses students' understanding of patterns, relations, and functions. In science, the LEAP 21 and ITBS test the same areas, with the exception of the added component of science and the environment on the LEAP 21 test. The same areas of social studies are assessed on both the ITBS and LEAP 21 tests.

\section{Data Analysis Procedures for Student Test Scores}

To answer research questions 1, 2, and 3, three multivariate analyses of variance (MANOVAs) were performed to determine if groups differed on more than one dependent variable. Gall, Borg, and Gall (1996) defined MANOVA as "a statistical procedure that compares the amount of betweengroups variance in individuals' scores with the amount of within-groups variance" (p. 395). After performing MANOVA procedures to examine the difference in students' overall academic 
TABLE 1

Grade 4 LEAP 21 Achievement Levels

\begin{tabular}{|c|c|c|c|c|}
\hline Achievement Level & $\begin{array}{c}\text { English Language } \\
\text { Arts Scaled Score } \\
\text { Range }\end{array}$ & $\begin{array}{c}\text { Mathematics } \\
\text { Scaled Score } \\
\text { Range }\end{array}$ & $\begin{array}{c}\text { Science } \\
\text { Scaled Score } \\
\text { Range } \\
\end{array}$ & $\begin{array}{c}\text { Social Studies } \\
\text { Scaled Score } \\
\text { Range }\end{array}$ \\
\hline Advanced & $408-500$ & $419-500$ & $405-500$ & $399-500$ \\
\hline Proficient & $354-407$ & $370-418$ & $360-404$ & $353-398$ \\
\hline Basic & $301-353$ & $315-369$ & $306-359$ & $301-352$ \\
\hline Approaching Basic & 263-300 & $282-314$ & 263-305 & $272-300$ \\
\hline Unsatisfactory & 100-262 & $100-281$ & 100-262 & $100-271$ \\
\hline
\end{tabular}

Note. Adapted from the 2000-2001 Louisiana Interpretive Guide (Louisiana Department of Education, 2001).

TABLE 2

Comparison of LEAP 21 and ITBS Content

\begin{tabular}{|c|c|c|c|c|c|c|c|c|}
\hline & \multicolumn{2}{|c|}{$\begin{array}{c}\text { English } \\
\text { Language Arts }\end{array}$} & \multicolumn{2}{|l|}{ Mathematics } & \multicolumn{2}{|c|}{ Science } & \multicolumn{2}{|c|}{ Social Studies } \\
\hline $\begin{array}{l}\text { Content } \\
\text { Standards } \\
\text { Measured by } \\
\text { LEAP } 21 \text { and } \\
\text { GEE } 21\end{array}$ & \multicolumn{2}{|c|}{$\begin{array}{l}\text { Read, comprehend, } \\
\text { and respond to a } \\
\text { range of materials } \\
\text { Write competently; } \\
\text { use conventions of } \\
\text { language } \\
\text { Apply speaking and } \\
\text { listening skills (not } \\
\text { assessed) } \\
\text { Locate, select, and } \\
\text { synthesize } \\
\text { information } \\
\text { Read, analyze, and } \\
\text { respond to } \\
\text { literature } \\
\text { Apply reasoning and } \\
\text { problem-solving } \\
\text { skills }\end{array}$} & \multicolumn{2}{|c|}{$\begin{array}{l}\text { Number and number } \\
\text { relations } \\
\text { Algebra } \\
\text { Measurement } \\
\text { Geometry } \\
\text { Data analysis, } \\
\text { probability, and } \\
\text { discrete math } \\
\text { Patterns, relations, } \\
\text { and functions }\end{array}$} & \multicolumn{2}{|c|}{$\begin{array}{l}\text { Science as inquiry } \\
\text { Physical Science } \\
\text { Life Science } \\
\text { Earth and Space } \\
\text { Science } \\
\text { Science and the } \\
\text { Environment }\end{array}$} & \multicolumn{2}{|c|}{$\begin{array}{l}\text { Geography: Physical } \\
\text { and Cultural } \\
\text { Systems } \\
\text { Civics: Citizenship } \\
\text { and Government } \\
\text { Economics: } \\
\text { Independence } \\
\text { and Decision } \\
\text { Making } \\
\text { History: Time, } \\
\text { Continuity, and } \\
\text { Change }\end{array}$} \\
\hline \multirow[t]{2}{*}{$\begin{array}{l}\text { Areas } \\
\text { Measured } \\
\text { by ITBS }\end{array}$} & eading & Language & Mathematics & & Science & & & $\begin{array}{l}\text { Sources of } \\
\text { Information }\end{array}$ \\
\hline & $\begin{array}{l}\text { bulary } \\
\text { ing } \\
\text { mprehen- } \\
\text { n }\end{array}$ & $\begin{array}{l}\text { Spelling } \\
\text { Capitalization } \\
\text { Punctuation } \\
\text { Usage } \\
\text { Expression }\end{array}$ & $\begin{array}{l}\text { Number and } \\
\text { number } \\
\text { relations } \\
\text { Algebra } \\
\text { Measurement } \\
\text { Geometry } \\
\text { Data analysis, } \\
\text { probability, and } \\
\text { discrete math } \\
\text { Patterns, relations, } \\
\text { and functions }\end{array}$ & $\begin{array}{r}\text { Scien } \\
\text { Physi } \\
\text { Sci } \\
\text { Life } \\
\text { Earth } \\
\text { Sci } \\
\text { Scien } \\
\text { En }\end{array}$ & $\begin{array}{l}\text { ce as inquiry } \\
\text { cal } \\
\text { ence } \\
\text { science } \\
\text { and Space } \\
\text { ence } \\
\text { ce and the } \\
\text { vironment }\end{array}$ & $\begin{array}{r}\text { Geogra } \\
\text { Phys } \\
\text { Cult } \\
\text { Syste } \\
\text { Civics: } \\
\text { Citiz } \\
\text { and } \\
\text { Gove } \\
\text { Econor } \\
\text { depe } \\
\text { and } \\
\text { Maki } \\
\text { History } \\
\text { Cont } \\
\text { and }\end{array}$ & $\begin{array}{l}\text { hy: } \\
\text { al and } \\
\text { ral } \\
\text { ns } \\
\text { nship } \\
\text { nment } \\
\text { ics: In- } \\
\text { dence } \\
\text { ecision } \\
\text { Time, } \\
\text { nuity, } \\
\text { hange }\end{array}$ & $\begin{array}{l}\text { Maps } \\
\text { Diagrams } \\
\text { Reference }\end{array}$ \\
\hline
\end{tabular}

Note. LEAP 21 (Louisiana Department of Education, 2001), ITBS (The Iowa Tests of Basic Skills, 2001). 
performance between groups, follow-up analysis of variance (ANOVA) procedures were performed to compare differences in scores in each subject area of the Grade 3 and Grade 5 ITBS and fourth-grade LEAP 21 tests.

Multivariate analyses of covariance (MANCOVAs) were used to investigate research questions 4, 5, and 6. According to Davis (2003), "MANCOVA determines whether there are statistically reliable mean differences among groups, after adjusting a newly created dependent measure on one or more covariates" (p. 1). The covariates for the research questions are indicated here.

For research question 4, students' Grade 3 ITBS reading, language, math, social studies, and science subtest scores are used as covariates. For research question 5, the LEAP 21 English language arts, math, science, and social studies subtest scores are used as covariates. For research question 6, the Grade 3 ITBS reading, language, math, social studies, and science subtest scores are used as covariates. For research questions 4 through 6, after employing MANCOVA procedures to investigate the overall difference between the groups' academic performance, followup $t$-tests were then performed for these questions to compare differences in the groups' scores in each subject area of the Grade 5 ITBS and Grade 4 LEAP 21 tests. In the present study, the MANCOVA procedures allowed for an examination of the longitudinally cumulative effect of students' participation in the Louisiana Elementary Foreign Language Program. Furthermore, they revealed how FL contributes to gains in the treatment groups' academic performance. For all statistical procedures, the hypotheses were tested at the .05 level of significance. For each procedure, effect size is calculated using the $\eta^{2}$ value. The $\eta^{2}$ value is the proportion of variation in groups' performance that is attributable to the particular effect, which in the case of the present research is FL study.

\section{RESULTS}

\section{Overview of Statistical Procedures}

To investigate research questions 1,2 , and 3 , a MANOVA procedure was performed for the variables in each question to compare the means between the treatment and control groups. If warranted by overall statistically significant differences, follow-up ANOVAs were then performed for each subset to determine where differences in these groups' academic performance on the ITBS and LEAP 21 subtests occurred.
To investigate research questions 4,5 , and 6 , in which a covariate was included, MANCOVA procedures were performed for each question. This procedure allowed for an examination of whether the overall academic performance of the treatment (FL study) and the control (no FL study) groups differed after adjusting for the covariate. Because there are multiple subtests of the ITBS as well as the LEAP 21 and because ITBS scores are intercorrelated, as are LEAP 21 scores, a MANCOVA is an efficient procedure to use because it can take into account the covariance among ITBS or LEAP 21 subtest scores and can answer questions about the differences between the control and treatment groups on the ITBS or LEAP 21 tests as an overall academic performance index. Whereas the MANOVA procedures for research questions 1, 2, and 3 were followed up with ANOVA procedures, the MANCOVA procedures were followed up with $t$-tests to discern differences in subtest scores. For each procedure, effect size is noted and discussed using the $\eta^{2}$ value.

\section{Results of Research Questions Investigating Student Participants' Academic Achievement}

Research Question 1. Do Grade 3 students participating in the Louisiana Foreign Language Elementary School program for the first year have significantly higher scores than their non-FL peers on the ITBS, which includes the combination of reading, language, math, science, and social studies subtest scores?

The dependent variables for research question 1 were the reading, language, mathematics, social studies, and science subtest scores of the Grade 3 ITBS. The independent variable was participation in the Louisiana Foreign Language Elementary School program. Results of the MANOVA procedure indicated that there were statistically significant differences between the treatment (FL) and control (non-FL) groups as demonstrated by Wilks's lambda $(5,1737)=.988, p<.05$ (see Table 3$)$. Although this is indicative of overall differences between the two groups, group membership explained slightly more than $1 \%$ of the variation in ITBS scores.

Follow-up ANOVA results obtained from the Grade 3 ITBS subtest scores show that the treatment group had higher scores in reading, language, math, and social studies; however, these scores were not significantly different. The science subtest shows that the control group students significantly outperformed those in the treatment group $(F=6.20 ; p<.05)$. 
TABLE 3

Summary of MANOVA Results on FL and Non-FL Students' Third-Grade ITBS Subtest Scores

\begin{tabular}{|c|c|c|c|c|c|c|c|c|c|}
\hline & \multicolumn{3}{|c|}{ Experimental Group } & \multicolumn{3}{|c|}{ Control Group } & \multirow[b]{2}{*}{$F$-Value } & \multirow[b]{2}{*}{$p$-Value } & \multirow[b]{2}{*}{$\eta^{2}$} \\
\hline & $\begin{array}{c}\text { Mean Standard } \\
\text { Score }\end{array}$ & $\begin{array}{l}\text { Standard } \\
\text { Deviation }\end{array}$ & $n$ & $\begin{array}{c}\text { Mean Standard } \\
\text { Score }\end{array}$ & $\begin{array}{l}\text { Standard } \\
\text { Deviation }\end{array}$ & $n$ & & & \\
\hline Reading & 175.35 & 19.03 & 1050 & 174.92 & 18.78 & 802 & 3.04 & .081 & .002 \\
\hline Language & 184.95 & 24.13 & 1042 & 183.96 & 22.31 & 721 & 0.33 & .565 & .000 \\
\hline Math & 178.25 & 19.83 & 1042 & 176.91 & 19.15 & 793 & 0.27 & .603 & .000 \\
\hline Social Studies & 176.18 & 18.19 & 1048 & 175.40 & 17.21 & 798 & 0.59 & .441 & .000 \\
\hline Science & 175.38 & 19.42 & 1048 & 176.24 & 20.05 & 798 & 6.20 & $.012^{* *}$ & .004 \\
\hline \multicolumn{2}{|c|}{ Wilks's lambda } & \multicolumn{2}{|c|}{$F$-Value } & \multicolumn{2}{|c|}{ Numerator $d f$} & \multicolumn{2}{|c|}{ Denominator $d f$} & $\begin{array}{r}p \text {-Val } \\
.001^{*}\end{array}$ & \\
\hline
\end{tabular}

Note. $\mathrm{df}=$ degrees of freedom.

${ }^{* *}$ Statistical significance at $\alpha=.01$.

${ }^{* * *}$ Statistical significance at $\alpha=.001$.

Given these results, the null hypothesis that Grade 3 students participating in the Louisiana Foreign Language Elementary School program of study for the first year do not have significantly higher scores than their non-FL peers on the combination of the reading, language, math, and social studies subtests of the ITBS is rejected as indicated by the statistically significant multivariate test, Wilks's lambda, as reported previously. Post hoc examination of univariate differences indicated that science was the only subtest yielding significant differences such that non-FL students outperformed their FL counterparts.

Research Question 2. Do Grade 4 students participating in the Louisiana Foreign Language Elementary School program for the second year have significantly higher scores than their non-FL peers on the LEAP 21, which includes the combination of English language arts, math, science, and social studies subtest scores?
The dependent variables for research question 2 were the English language arts, mathematics, science, and social studies subtest scores of the LEAP 21. The independent variable was participation in the Louisiana Foreign Language Elementary School program.

Table 4 shows the results of the MANOVA procedure performed for research question 2. The null hypothesis was rejected based on statistically significant overall differences between the treatment (FL) and control (non-FL) groups, as indicated by Wilks's lambda $(4,1979)=.987$, $p<.05$.

Follow-up ANOVAs done on the Grade 4 LEAP 21 subtests show that the treatment group had significantly higher scores on each subtest in the following order of magnitude: Language $(F=18.71$; $p=.0001)$; social studies $(F=15.46 ; p=.0001)$; science $(F=12.70 ; p=.0004)$; and mathematics $(F=11.51 ; p=.0007)$. The largest effect size was for the difference in language subtest scores

TABLE 4

Summary of MANOVA Results on Foreign Language and Non-Foreign Language Students' Fourth-Grade LEAP 21 Subtest Scores

\begin{tabular}{|c|c|c|c|c|c|c|c|c|c|}
\hline & \multicolumn{3}{|c|}{ Experimental Group } & \multicolumn{3}{|c|}{ Control Group } & \multirow[b]{2}{*}{$F$-value } & \multirow[b]{2}{*}{$p$-Value } & \multirow[b]{2}{*}{$\eta^{2}$} \\
\hline & $\begin{array}{c}\text { Mean Standard } \\
\text { Score }\end{array}$ & $\begin{array}{l}\text { Standard } \\
\text { Deviation }\end{array}$ & $n$ & $\begin{array}{c}\text { Mean Standard } \\
\text { Score }\end{array}$ & $\begin{array}{l}\text { Standard } \\
\text { Deviation }\end{array}$ & $n$ & & & \\
\hline Language & 312.42 & 55.04 & 849 & 299.41 & 60.28 & 635 & 18.71 & $.0001^{* * * *}$ & .012 \\
\hline Math & 315.87 & 53.18 & 849 & 305.79 & 61.09 & 635 & 11.51 & $.0007^{* * *}$ & .008 \\
\hline Science & 300.74 & 54.84 & 849 & 289.70 & 61.27 & 636 & 12.70 & $.0004^{* * *}$ & .008 \\
\hline Social Studies & 301.51 & 53.48 & 849 & 289.93 & 56.72 & 636 & 15.46 & $.0001^{* * * *}$ & .010 \\
\hline \multicolumn{2}{|c|}{ Wilks’s lambda } & \multicolumn{2}{|c|}{$F$-value } & \multicolumn{2}{|c|}{ Numerator $d f$} & \multicolumn{2}{|c|}{ Denominator $d f$} & $.0006^{* * *}$ & \\
\hline
\end{tabular}

Note. $\mathrm{df}=$ degrees of freedom.

*** Statistical significance at $\alpha=.001$.

**** Statistical significance at $\alpha=.0001$. 
$\left(\eta^{2}=.012\right)$. This is indicative of a small difference (Cohen, 1977).

To more fully investigate research question 2, numbers and percentages of students comprising both the treatment (FL) and control (nonFL) groups scoring at each performance level of the Grade 4 LEAP 21 English language arts, mathematics, science, and social studies subtests were determined. This allowed for a comparison of each group's performance level attainment on all LEAP 21 subtests. LEAP 21 performance level designations, in order of highest to lowest achievement category, are as follows: Advanced, Proficient, Basic, Approaching Basic, and Unsatisfactory. It should be noted that students must score in the Approaching Basic level or above to pass a given subject area.

Table 5 shows the numbers and percentages of students scoring at each performance level of the LEAP 21 English language arts subtest. Figure 1 represents these percentages in a bar graph, which enables the reader to visualize the differences in both groups' attainment at each performance level. When comparing percentages of both groups' attainment at each performance level, the treatment group had 1\% more students scoring at the Advanced level, $2 \%$ more at the Proficient level, and 5\% more at the Basic level than did the control group. Both groups had an equal number of students scoring at the

TABLE 5

Numbers and Percentages of FL and Non-FL Students Scoring at Each Performance Level of the English Language Arts Subtest of the Fourth-Grade LEAP 21

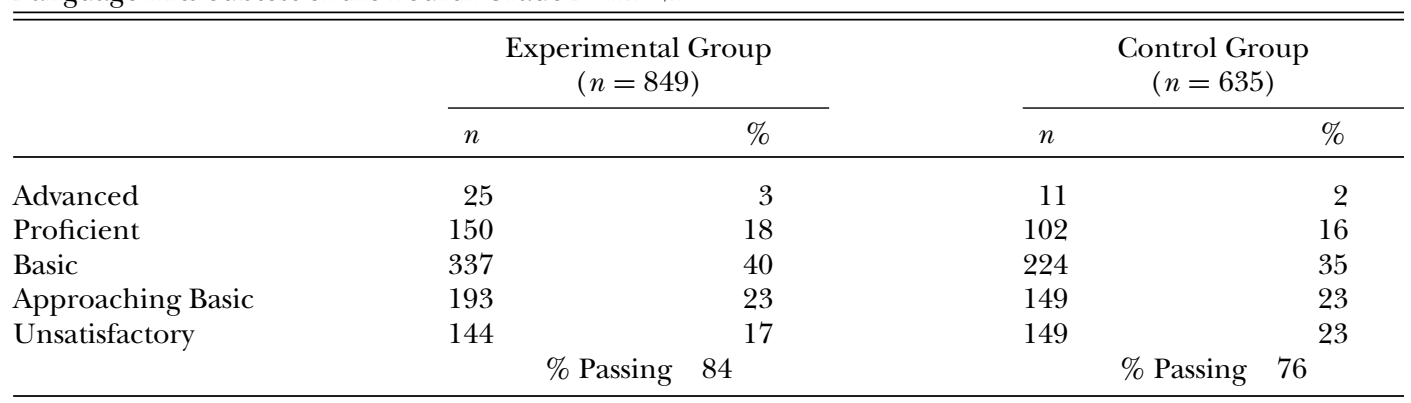

\section{FIGURE 1}

Percentages of FL and Non-FL Students Scoring at Each Achievement Level of the Fourth-Grade LEAP 21 English Language Arts Subtest

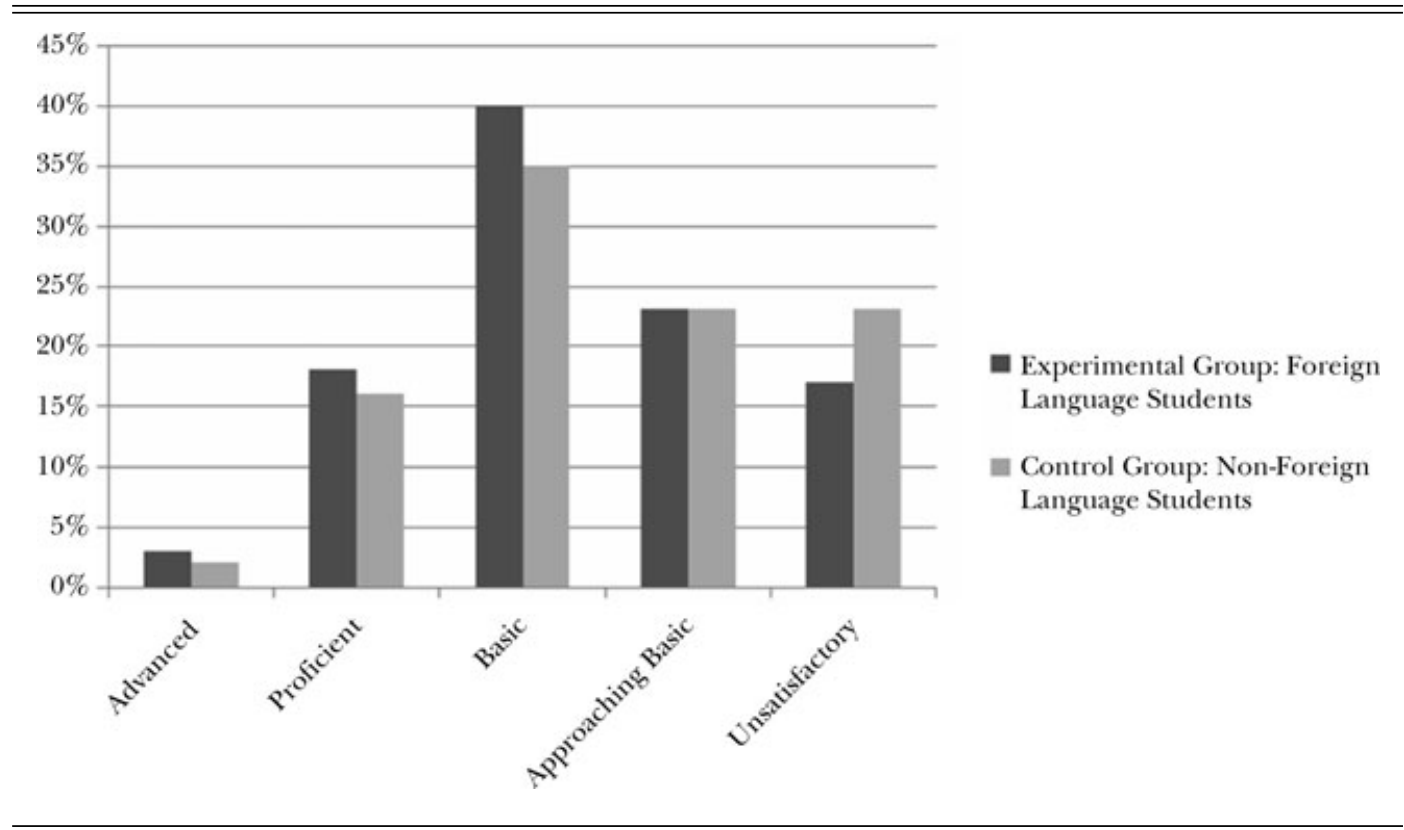


TABLE 6

Numbers and Percentages of FL and Non-FL Students Scoring at Each Performance Level of the Mathematics Subtest of the Fourth-Grade LEAP 21

\begin{tabular}{|c|c|c|c|c|}
\hline & \multicolumn{2}{|c|}{$\begin{array}{l}\text { Experimental Group } \\
\qquad(n=849)\end{array}$} & \multicolumn{2}{|c|}{$\begin{array}{l}\text { Control Group } \\
\quad(n=635)\end{array}$} \\
\hline & $n$ & $\%$ & $n$ & $\%$ \\
\hline Advanced & 16 & 2 & 12 & 2 \\
\hline Proficient & 94 & 11 & 56 & 9 \\
\hline Basic & 360 & 42 & 243 & 38 \\
\hline Approaching Basic & 171 & 20 & 132 & 21 \\
\hline \multirow{2}{*}{ Unsatisfactory } & 208 & 24 & 192 & 30 \\
\hline & & 75 & & 70 \\
\hline
\end{tabular}

Approaching Basic level. Six percent more students in the control group scored in the Unsatisfactory category compared to those in the treatment group. Whereas $84 \%$ of the treatment group students passed the English language arts subtest of the LEAP 21, only $76 \%$ of the control group students did. This is a difference of $8 \%$ in favor of the treatment group students.

Table 6 shows the numbers and percentages of students scoring at each performance level of the LEAP 21 mathematics subtest. Figure 2 represents these percentages in a bar graph. When comparing percentages of both groups' attainment at each performance level, each group had an equal number of students scoring at the Advanced level. The treatment group had $2 \%$ more students scoring at the Proficient level and $4 \%$ more at the Basic level than did the control group. One percent more students in the control group scored at the Approaching Basic level compared to those in the treatment group. Six percent more students in the control group scored in the Unsatisfactory category compared to those in the treatment group. Whereas $75 \%$ of the treatment group students passed the mathematics subtest of the LEAP 21 , only $70 \%$ of the control group students did. This is a difference of $5 \%$ in favor of the treatment group students.

\section{FIGURE 2}

Percentages of FL and Non-FL Students Scoring at Each Achievement Level of the Fourth-Grade LEAP 21 English Mathematics Subtest

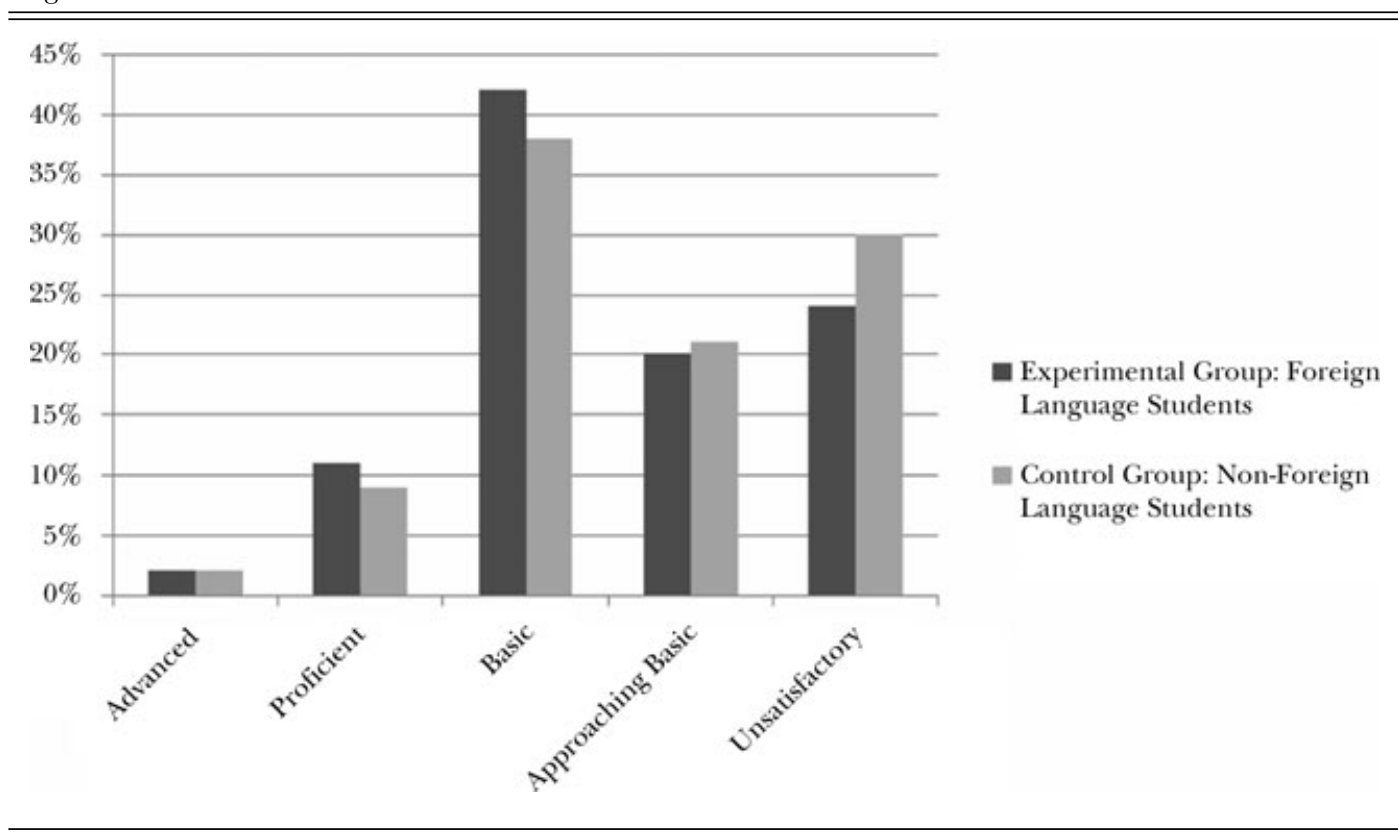


TABLE 7

Numbers and Percentages of FL and Non-FL Students Scoring at Each Performance Level of the Science Subtest of the Fourth-Grade LEAP 21

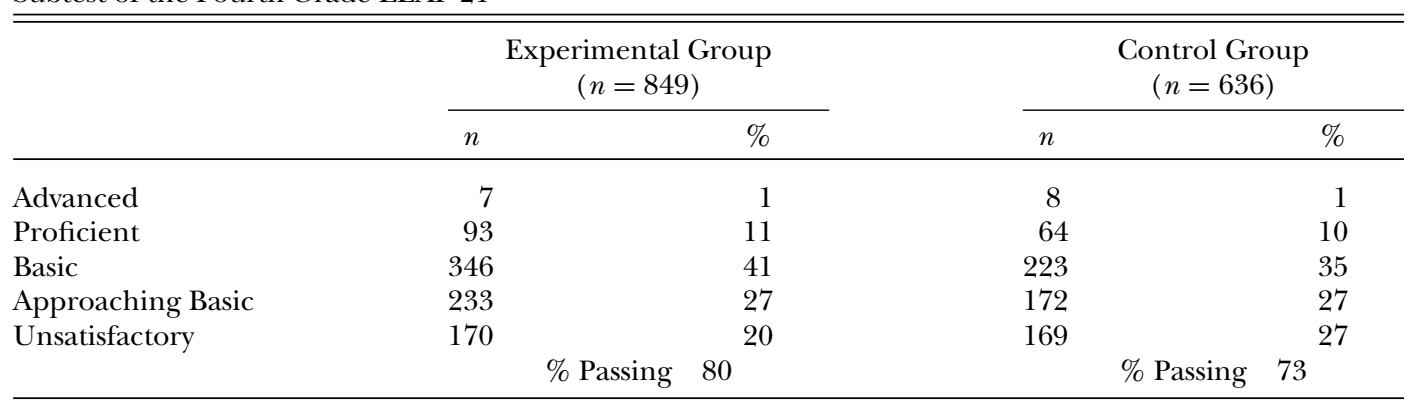

\section{FIGURE 3}

Percentages of FL and Non-FL Students Scoring at Each Achievement Level of the Fourth-Grade LEAP 21 Science Subtest

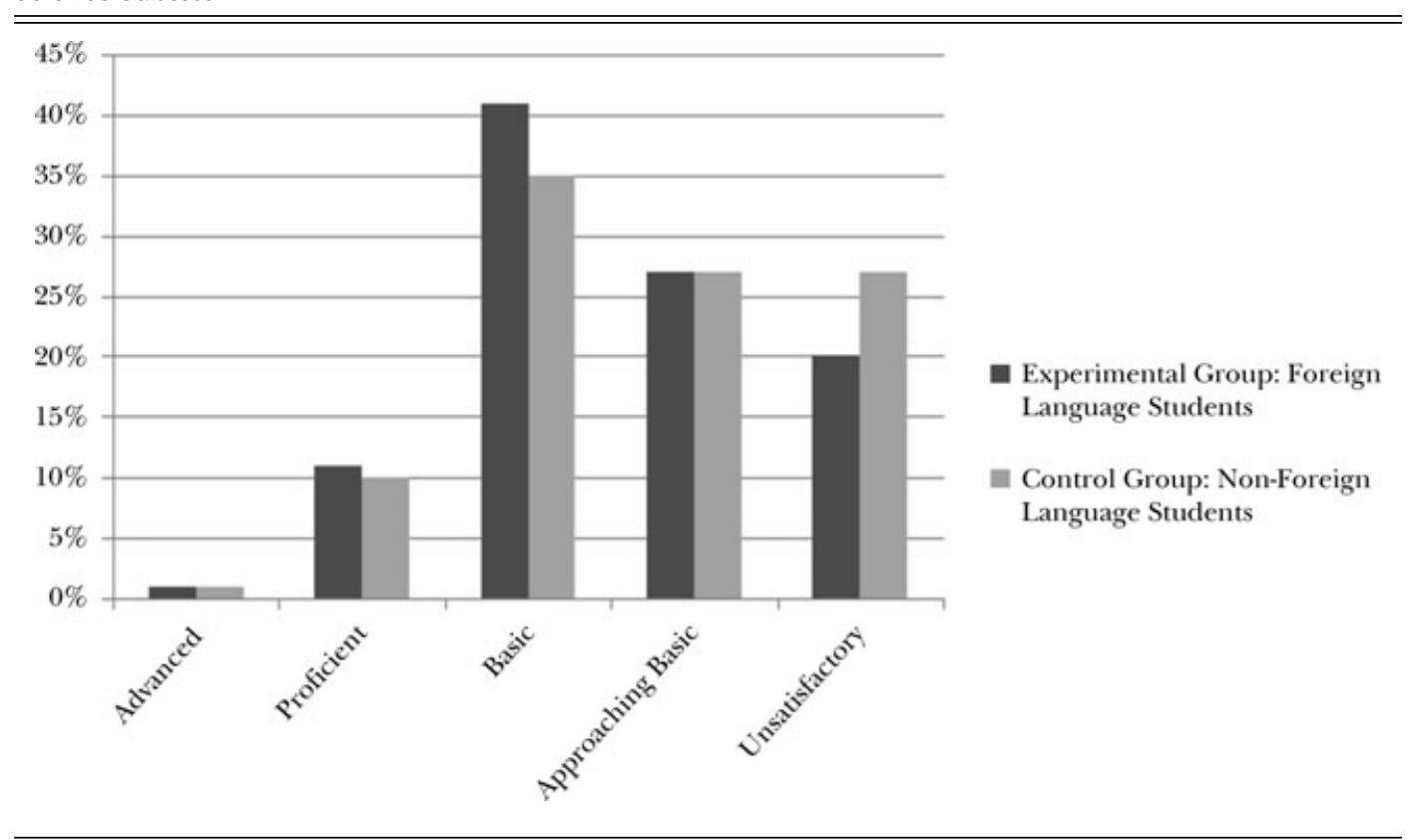

Table 7 shows the numbers and percentages of students scoring at each performance level of the LEAP 21 science subtest. Figure 3 represents these percentages in a bar graph. When comparing percentages of both groups' attainment at each performance level, each group had an equal number of students scoring at the Advanced level as well as the Approaching Basic level. The treatment group had $1 \%$ higher attainment at the Proficient level and 6\% higher attainment at the Basic level than did the control group. Seven percent more students in the control group scored in the Unsatisfactory category compared to those in the treatment group. Eighty percent of the treat- ment group students passed the science subtest of the LEAP 21; only $73 \%$ of the control group students did. This $7 \%$ difference favors the treatment group students.

Table 8 shows the numbers and percentages of students scoring at each performance level of the LEAP 21 social studies subtest. Figure 4 represents these percentages in a bar graph. When comparing percentages of both groups' attainment at each performance level, the treatment group had $1 \%$ higher attainment at the Advanced level and $5 \%$ higher attainment at the Proficient level than did the control group. Both groups had an equal number of students scoring at the Basic level. 
TABLE 8

Numbers and Percentages of FL and Non-FL Students Scoring at Each Performance Level of the Social Studies Subtest of the Fourth-Grade LEAP 21

\begin{tabular}{|c|c|c|c|c|}
\hline & \multicolumn{2}{|c|}{$\begin{array}{c}\text { Experimental } \\
\text { Group }(n=849)\end{array}$} & \multicolumn{2}{|c|}{$\begin{array}{c}\text { Control } \\
\text { Group }(n=636)\end{array}$} \\
\hline & $n$ & $\%$ & $n$ & $\%$ \\
\hline Advanced & 19 & 2 & 7 & 1 \\
\hline Proficient & 116 & 14 & 58 & 9 \\
\hline Basic & 309 & 36 & 227 & 36 \\
\hline Approaching Basic & 190 & 22 & 154 & 24 \\
\hline \multirow[t]{2}{*}{ Unsatisfactory } & 215 & 25 & 190 & 30 \\
\hline & \multicolumn{2}{|c|}{$\%$ Passing } & \multicolumn{2}{|c|}{$\%$ Passing 70} \\
\hline
\end{tabular}

FIGURE 4

Percentages of FL and Non-FL Students Scoring at Each Achievement Level of the Fourth-Grade LEAP 21 English Social Studies Subtest

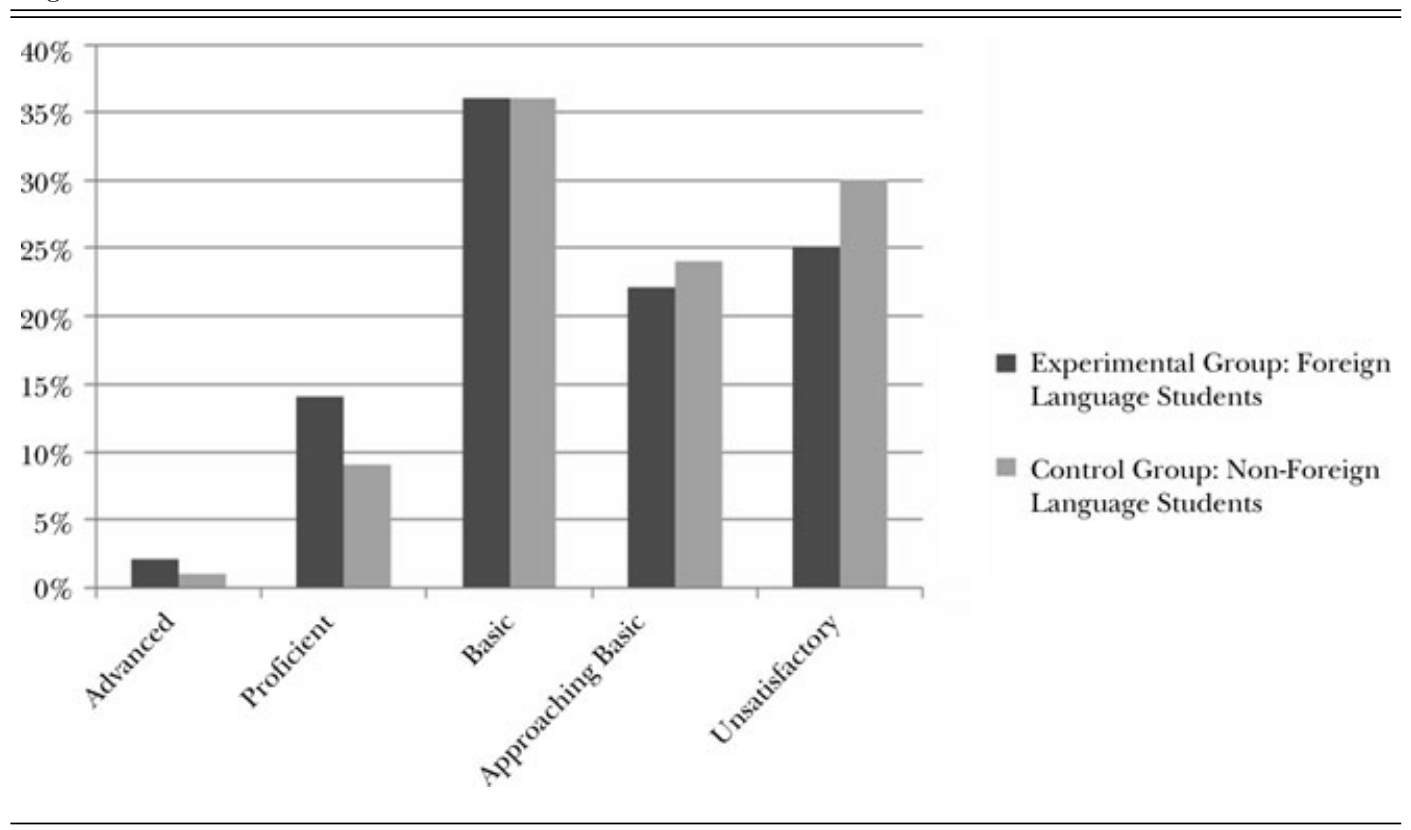

The control group had $1 \%$ higher attainment at the Approaching Basic level, whereas 5\% more students in the control group scored at the unsatisfactory level compared to those in the treatment group. Whereas $74 \%$ of the treatment group students passed the social studies subtest of the LEAP 21 , only $70 \%$ of the control group students did. This is a difference of $4 \%$ in favor of the treatment group students.

Research Question 3. Do Grade 5 students participating in the Louisiana Foreign Language Elementary School program for the third year have significantly higher scores than their non-FL peers on the ITBS, which includes the combination of reading, language, math, social studies, and science subtests?

The dependent variables for research question 3 were the reading, language, mathematics, social studies, and science subtests of the Grade 5 ITBS. The independent variable was participation in the Louisiana Foreign Language Elementary School program.

Table 9 shows the results of the MANOVA performed to investigate research question 3 . There were significant differences overall between the treatment (FL) and control (non-FL) groups, as indicated by Wilks's lambda $(5,1002)=.963$, 
TABLE 9

Summary of MANOVA Results on FL and Non-FL Students' Fifth-Grade ITBS Subtest Scores

\begin{tabular}{|c|c|c|c|c|c|c|c|c|c|}
\hline & \multicolumn{3}{|c|}{ Experimental Group } & \multicolumn{3}{|c|}{ Control Group } & \multirow[b]{2}{*}{$F$-Value } & \multirow[b]{2}{*}{$p$-Value } & \multirow[b]{2}{*}{$\eta^{2}$} \\
\hline & $\begin{array}{c}\text { Mean Standard } \\
\text { Score }\end{array}$ & $\begin{array}{l}\text { Standard } \\
\text { Deviation }\end{array}$ & $n$ & $\begin{array}{c}\text { Mean Standard } \\
\text { Score }\end{array}$ & $\begin{array}{l}\text { Standard } \\
\text { Deviation }\end{array}$ & $n$ & & & \\
\hline Reading & 209.61 & 19.30 & 609 & 211.18 & 20.17 & 399 & 1.54 & .214 & .002 \\
\hline Language & 223.52 & 26.57 & 609 & 219.10 & 27.18 & 399 & 6.55 & $.010^{* *}$ & .006 \\
\hline Math & 214.11 & 22.02 & 609 & 215.43 & 21.89 & 399 & 0.87 & .351 & .001 \\
\hline Social Studies & 210.90 & 24.77 & 609 & 214.70 & 23.68 & 399 & 5.83 & $.015^{*}$ & .006 \\
\hline Science & 212.97 & 30.99 & 609 & 214.70 & 31.28 & 399 & 0.75 & .387 & .001 \\
\hline \multicolumn{2}{|c|}{$\begin{array}{c}\text { Wilks's lambda } \\
.963\end{array}$} & \multicolumn{2}{|c|}{$\begin{array}{c}F \text {-Value } \\
7.60\end{array}$} & \multicolumn{2}{|c|}{ Numerator $d f$} & Denominator $d f$ & $\begin{array}{l}\text { minator } d f \\
1002\end{array}$ & $\begin{array}{l}p \text {-Valu } \\
.0001^{*}\end{array}$ & \\
\hline
\end{tabular}

${ }^{*}$ Statistical significance at $\alpha=.05$.

${ }^{* *}$ Statistical significance at $\alpha=.01$.

${ }^{* * * *}$ Statistical significance at $\alpha=.0001$.

TABLE 10

Summary of MANCOVA Results on FL and Non-FL Students' Fourth-Grade LEAP 21 Subtest Scores Including Students' Third-Grade ITBS Reading, Language, Mathematics, Social Studies, and Science Subtest Scores as Covariates

\begin{tabular}{|c|c|c|c|c|c|c|c|c|c|}
\hline & \multicolumn{3}{|c|}{ Experimental Group } & \multicolumn{3}{|c|}{ Control Group } & \multirow[b]{2}{*}{$t$} & \multirow[b]{2}{*}{$p$-Value } & \multirow[b]{2}{*}{$\eta^{2}$} \\
\hline & $\begin{array}{c}\text { LS Mean } \\
\text { Standard Score }\end{array}$ & $\begin{array}{c}\text { Standard } \\
\text { Error }\end{array}$ & $n$ & $\begin{array}{c}\text { LS Mean } \\
\text { Standard Score }\end{array}$ & $\begin{array}{c}\text { Standard } \\
\text { Error }\end{array}$ & $n$ & & & \\
\hline Language & 313.27 & 1.16 & 849 & 306.48 & 1.41 & 635 & -3.70 & $.0002^{* * *}$ & .008 \\
\hline Math & 316.12 & 1.18 & 849 & 313.28 & 1.44 & 635 & -1.51 & .1313 & .001 \\
\hline Science & 301.83 & 1.19 & 849 & 296.08 & 1.45 & 636 & -3.04 & $.0024^{* *}$ & .006 \\
\hline Social Studies & 302.39 & 1.08 & 849 & 296.50 & 1.32 & 636 & -3.42 & $.0006^{* * *}$ & .007 \\
\hline \multicolumn{2}{|c|}{ Wilks's lambda } & \multicolumn{2}{|c|}{$F$-Value } & \multicolumn{2}{|c|}{ Numerator $d f$} & \multicolumn{2}{|c|}{ Denominator $d f$} & $\begin{array}{l}p \text {-Valu } \\
.0005^{*}\end{array}$ & \\
\hline
\end{tabular}

** Statistical significance at $\alpha=.01$.

*** Statistical significance at $\alpha=.001$.

$p<.05$. Given these results, the null hypothesis of an overall difference was rejected.

The ANOVAs performed on the Grade 5 ITBS subtests show that there were no statistically significant differences between groups on measures of reading, math, and science. However, the treatment group and control group differed significantly in mean performance on measures of social studies $(F=5.83 ; p=.015)$ and language $(F=6.55 ; p=.010)$. These results were mixed: The control group outperformed the treatment group in social studies; however, the treatment group's language scores were statistically greater than those of the control group.

Research Question 4. After adjusting for prior performance on the Grade 3 ITBS, do Grade 4 students after 2 years of participation in the Louisiana Foreign Language Elementary School program make significantly greater academic gains on the combination of Grade 4 LEAP 21 subtest scores than their non-FL peers?

The statistical analyses performed for research question 4 allowed us to see if Louisiana Elementary Foreign Language Program participants had significantly higher academic gains than their non-FL counterparts by controlling for students' Grade 3 ITBS scores.

The dependent variables for research question 4 were the LEAP 21 English language arts, mathematics, science, and social studies subtest scores. The independent variable was participation in the Louisiana Foreign Language Elementary School program. The Grade 3 ITBS reading, language, math, social studies, and science subtest scores were used as covariates.

Table 10 shows the results of the MANCOVA performed for research question 4. Statistically significant overall differences as demonstrated by Wilks's lambda $(4,1396)=.986, p<.05$, were 
TABLE 11

Summary of MANCOVA Results on FL and Non-FL Students' Fifth-Grade ITBS Subtest Scores Including Students' Fourth-Grade LEAP 21 Language, Mathematics, Science, and Social Studies Subtest Scores as Covariates

\begin{tabular}{|c|c|c|c|c|c|c|c|c|c|}
\hline & \multicolumn{3}{|c|}{ Experimental Group } & \multicolumn{3}{|c|}{ Control Group } & \multirow[b]{2}{*}{$t$} & \multirow[b]{2}{*}{$p$-Value } & \multirow[b]{2}{*}{$\eta^{2}$} \\
\hline & $\begin{array}{c}\text { LS Mean } \\
\text { Standard Score }\end{array}$ & $\begin{array}{l}\text { Standard } \\
\text { Error }\end{array}$ & $n$ & $\begin{array}{c}\text { LS Mean } \\
\text { Standard Score }\end{array}$ & $\begin{array}{c}\text { Standard } \\
\text { Error }\end{array}$ & $n$ & & & \\
\hline Reading & 209.52 & 0.50 & 609 & 211.20 & 0.63 & 399 & 2.06 & $.0393^{*}$ & .004 \\
\hline Language & 223.58 & 0.73 & 609 & 219.23 & 0.91 & 399 & -3.69 & $.0002^{* * *}$ & .011 \\
\hline Math & 214.52 & 0.57 & 609 & 214.85 & 0.71 & 399 & 0.36 & .7158 & .0001 \\
\hline Social Studies & 210.99 & 0.68 & 609 & 214.43 & 0.84 & 399 & 3.16 & $.0016^{* *}$ & .009 \\
\hline Science & 213.00 & 0.88 & 609 & 214.32 & 1.10 & 399 & 0.93 & .3528 & .0008 \\
\hline \multicolumn{2}{|c|}{$\begin{array}{c}\text { Wilks's lambda } \\
.966\end{array}$} & \multicolumn{2}{|c|}{$F$-Value } & \multicolumn{2}{|c|}{ Numerator $d f$} & \multicolumn{2}{|c|}{ Denominator $d f$} & \multicolumn{2}{|c|}{$.0001^{* * * *}$} \\
\hline
\end{tabular}

* Statistical significance at $\alpha=.05$.

${ }^{* *}$ Statistical significance at $\alpha=.01$.

*** Statistical significance at $\alpha=.001$.

**** Statistical significance at $\alpha=.0001$.

found between the treatment (FL) and control (non-FL) groups, indicating that the null hypothesis was rejected.

Follow-up $t$-tests performed on the least adjusted squared means of the Grade 4 LEAP 21 subtests yielded statistically significant results in favor of the treatment group in three of four areas. That is to say, English language arts, science, and social studies performance favored the FL students. Although the treatment group achieved higher scores on the mathematics subtest, this difference was not significant. In contrast, the treatment group earned significantly higher scores on all other measures in the following order of magnitude: Language $(t=-3.70 ; p=.0002)$; social studies $(t=-3.42 ; p=.0006)$; and science $(t=$ $-3.04 ; p=.0024)$. It should be noted that although the results are indicative of positive differences for the treatment group, the magnitudes of the differences are small $\left(\eta^{2} \leq .008\right.$; Cohen, 1977).

Research Question 5. After adjusting for prior performance on the Grade 3 ITBS, do Grade 4 students after 2 years of participation in the Louisiana Foreign Language Elementary School program make significantly greater academic gains on the combination of Grade 4 LEAP 21 subtest scores than their non-FL peers?

The statistical analyses performed for research question 5 allowed us to see if Louisiana Elementary Foreign Language Program participants had significantly higher academic gains than their non-FL counterparts by controlling their Grade 4
LEAP 21 subtest scores. The dependent variables were the Grade 5 ITBS reading, language, mathematics, social studies, and science subtest scores. The independent variable was participation in the Louisiana Foreign Language Elementary School program. The Grade 4 LEAP 21 language, math, science, and social studies subtest scores were used as covariates.

Table 11 shows the results of the MANCOVA procedure performed for research question 5 . Statistically significant overall differences existed between the treatment (FL) and control (non-FL) groups after adjusting for Grade 4 LEAP scores, as evidenced by Wilks's lambda $(5,988)=.966, p<$ .05 . Individual $t$-tests on the least squared means were performed on the Grade 5 ITBS subtests. Although the control group achieved higher scores on the math and science subtests, these differences were not statistically significant. In contrast, the control group did earn significantly higher scores on the reading $(t=2.06 ; p=.0393)$ and social studies $(t=3.16 ; p=.0016)$ subtests. The treatment group scored significantly higher than the control group on the language subtest $(t=$ $-3.69 ; p=.0002)$.

The null hypothesis was rejected overall. However, the differences were mixed in terms of subtest area and group membership. The greatest effect appeared to be the language subtest $\left(\eta^{2}=\right.$ .011 ), with the FL treatment group outperforming their non-FL counterparts.

Research Question 6. After adjusting for prior performance on the Grade 3 ITBS, do Grade 5 students after 3 years of participation in the 
TABLE 12

Summary of MANCOVA Results on FL and Non-FL Students' Fifth-Grade ITBS Subtest Scores Including Students' Third-Grade ITBS Reading, Language, Mathematics, Social Studies, and Science Subtest Scores as Covariates

\begin{tabular}{|c|c|c|c|c|c|c|c|c|c|}
\hline & \multicolumn{3}{|c|}{ Experimental Group } & \multicolumn{3}{|c|}{ Control Group } & \multirow[b]{2}{*}{$t$} & \multirow[b]{2}{*}{$p$-Value } & \multirow[b]{2}{*}{$\eta^{2}$} \\
\hline & $\begin{array}{c}\text { LS Mean } \\
\text { Standard Score }\end{array}$ & $\begin{array}{l}\text { Standard } \\
\text { Error }\end{array}$ & $n$ & $\begin{array}{c}\text { LS Mean } \\
\text { Standard Score }\end{array}$ & $\begin{array}{c}\text { Standard } \\
\text { Error }\end{array}$ & $n$ & & & \\
\hline Reading & 210.53 & 0.48 & 609 & 210.93 & 0.61 & 399 & 0.51 & .6112 & .0002 \\
\hline Language & 224.38 & 0.72 & 609 & 219.41 & 0.92 & 399 & -4.22 & $.0001^{* * * *}$ & .015 \\
\hline Math & 214.78 & 0.54 & 609 & 215.60 & 0.69 & 399 & 0.91 & .3607 & .0006 \\
\hline Social Studies & 212.03 & 0.68 & 609 & 214.00 & 0.87 & 399 & 1.76 & .0783 & .003 \\
\hline Science & 214.45 & 0.86 & 609 & 213.96 & 1.10 & 399 & -.34 & .7309 & .0001 \\
\hline \multicolumn{2}{|c|}{ Wilks's lambda } & \multicolumn{2}{|c|}{$F$-Value } & \multicolumn{2}{|c|}{ Numerator $d f$} & \multicolumn{2}{|c|}{ Denominator $d f$} & $.0001^{* * * *}$ & \\
\hline
\end{tabular}

**** Statistical significance at $\alpha=.0001$.

Louisiana Foreign Language Elementary School program make significantly greater academic gains on the combination of Grade 5 ITBS subtest scores than their non-FL peers after participating in the program from Grade 3 to Grade 5?

The statistical analyses performed for research question 6 examined Louisiana Elementary Foreign Language Program participants' cumulative academic gains from Grade 3 to Grade 5. This allowed us to see if FL participants had significantly higher academic gains than their non-FL counterparts over time after controlling for their Grade 3 ITBS subtest scores.

The dependent variables were the Grade 5 ITBS reading, language, mathematics, social studies, and science subtest scores. The independent variable was participation in the Louisiana Foreign Language Elementary School program. The Grade 3 ITBS reading, language, math, social studies, and science subtest scores were used as covariates.

Table 12 shows the results of the MANCOVA procedure performed for research question 6 . Significant overall differences existed between the treatment (FL) and control (non-FL) groups as demonstrated by Wilks's lambda $(5,969)=.967$, $p<.05$, thus indicating that the null hypothesis of no difference was rejected.

Individual $t$-tests using adjusted means performed on the Grade 5 ITBS subtests yield these results. Although the control group achieved higher scores on the reading, mathematics, and social studies subtests, these differences were not statistically significant. The treatment group achieved higher scores than the control group on the science subtest, but this difference was not significant. However, the treatment group achieved significantly higher scores on the language subtest $(t=-4.22 ; p=.0001)$. These results produced a small effect $\left(\eta^{2}=.015\right)$, as indicated by a difference of approximately 5 points on the language subtest scores.

\section{Significant Findings of the Study}

The performance of the treatment group (FL students) and control group (non-FL students) generally differed according to the test being investigated. The treatment group outperformed the control group, as demonstrated by statistically significant scores on every subtest of the Grade 4 LEAP 21. Moreover, the treatment group outperformed the control group, as evidenced by significant differences in Grade 5 ITBS language scores.

It is important to draw a clear distinction between the ITBS and LEAP 21 assessments. The ITBS is a norm-referenced test focusing on a narrow set of skills assessing prior knowledge and is entirely composed of multiple-choice items. In contrast, the LEAP 21 is a criterion-referenced test whose content is specifically based on the 1997 Louisiana Content Standards in the following curricular areas: English language arts, mathematics, science, and social studies. The LEAP 21 also tests students' prior knowledge but requires that students apply this knowledge by responding not only to multiple-choice items but also to constructed-response items and writing prompts, thereby invoking students' use of higher order thinking skills. Given that this format requires student-generated responses, partial credit is awarded to students when they demonstrate that they can apply content skills when given a particular task.

Appreciable differences were revealed when comparing groups' LEAP 21 test scores. In other 
words, the statistical procedures comparing both groups' performance on the Grade 4 LEAP 21 test indicated that the FL students significantly outperformed their non-FL counterparts on every subtest of the LEAP 21 test. Superior performance on all LEAP 21 measures was further evidenced when comparing FL students' LEAP 21 performance to their non-FL peers after 2 years of program participation using the prior year's ITBS scores as covariates. However, although the results of this latter procedure indicated that FL students' LEAP 21 mathematics scores were higher than those of the non-FL group, they were not significantly different. Even when Grade 3 ITBS subtest scores were accounted for, there were statistically significant differences in language scores, favoring the FL students. Performance on language subtests on both the Grade 5 ITBS as well as Grade 4 LEAP 21 was significantly higher for FL students than for non-FL students.

The treatment group's performance on the language subtests of both the ITBS and LEAP 21 was consistently significantly greater than that of the control group, except for the first year of the study. When comparing the ITBS reading scores, however, a different finding emerged. When examining student gains from Grade 4 to Grade 5, the control group significantly outperformed the treatment group on reading measures. Why did the FL students not demonstrate a significant reading advantage over the non-FL students in this isolated instance? The answer may lie, in part, in the teaching methods employed by the FL teachers of the student participants. First, FLES teachers emphasize oral language production and, to a lesser extent, written language production. Reading comprehension is minimally addressed. Second, perhaps the formats of the criterion-referenced LEAP 21 and the norm-referenced ITBS play a role. Whereas the ITBS assesses students' prior knowledge on narrow skills via multiple-choice questions, the LEAP 21 requires students to draw upon their prior knowledge and apply that knowledge to new situations in a format that includes constructedresponse items in addition to multiple-choice questions. A third consideration is that the LEAP 21 English language arts subtest requires students to apply their reasoning and problemsolving skills. The research based on the cognitive benefits of FL study indicates that enhanced problem-solving skills are a byproduct of second language learning. Landry (1973) related that second language study promotes figural creativity. In a subsequent study, Landry (1974) examined Grade 6 students who had studied an FL since
Grade 1 in comparison with their monolingual counterparts and found that divergent thinking skills among the former were higher. In the same vein, Hakuta (1990) found that second language study led to higher levels of metalinguistic awareness and cognitive ability among elementary students of Spanish compared to their monolingual peers.

\section{Discussion of Research Questions Investigating Student Participants' Academic Achievement}

Table 13 provides an overview of the results of the statistical analyses of the ITBS and LEAP 21 subtests and further denotes statistically significant differences between the groups' performances listed in order of magnitude of difference in performance from highest to lowest.

Research Question 1. Research question 1 used a MANOVA procedure and follow-up ANOVA to examine differences between the academic performance of non-FL students and FL students on the Grade 3 reading, language, mathematics, social studies, and science subtests of the ITBS.

A marginal difference in the science subtest favoring the non-FL students was evidenced. Moreover, Grade 5 ITBS performance indicates that over time, this difference dissipated. Although FL students outperformed their non-FL peers on the Grade 5 ITBS science subtest, the difference was not significant.

Research Questions 2 and 4. Research questions 2 and 4 investigated academic performance on the Grade 4 LEAP 21 state-developed test. Research question 2 used a MANOVA procedure and follow-up ANOVAs to examine differences between the academic performance of non-FL and FL students on the LEAP 21 English language arts, mathematics, science, and social studies subtests. Research question 4 used a MANCOVA procedure and follow-up $t$-tests on the adjusted means to examine differences between the academic performance on the LEAP 21 English language arts, mathematics, science, and social studies subtests of non-FL and FL students after 2 years of FL study. The MANCOVA procedure accounted for differences in student performance by controlling for Grade 3 reading, language, mathematics, social studies, and science ITBS scores.

The statistical analyses performed to answer research question 2 revealed that the FL students scored significantly higher than their monolingual counterparts in all subtests of the LEAP 21. To examine whether these differences were prevalent if prior academic achievement was included in the model, Grade 3 ITBS scores were used to 
TABLE 13

Results of Statistical Analyses of ITBS and LEAP 21 Subtests

\begin{tabular}{|c|c|c|}
\hline Statistical Procedure & $\begin{array}{c}\text { FL Students } \\
\text { (Treatment Group) }\end{array}$ & $\begin{array}{l}\text { Non-FL Students } \\
\text { (Control Group) }\end{array}$ \\
\hline $\begin{array}{l}\text { MANOVA and Follow-up ANOVAs } \\
\text { on Third-Grade ITBS }\end{array}$ & $\begin{array}{l}\text { Reading } \\
\text { Social Studies } \\
\text { Language } \\
\text { Mathematics }\end{array}$ & *Science \\
\hline $\begin{array}{l}\text { MANOVA on Follow-up ANOVAs } \\
\text { on Fourth-Grade LEAP } 21\end{array}$ & $\begin{array}{l}\text { *Language } \\
\text { *Social Studies } \\
\text { *Science } \\
\text { *Mathematics }\end{array}$ & \\
\hline $\begin{array}{l}\text { MANOVA and Follow-up ANOVAs } \\
\text { on Fifth-Grade ITBS }\end{array}$ & *Language & $\begin{array}{l}\text { *Social Studies } \\
\text { Reading } \\
\text { Mathematics } \\
\text { Science }\end{array}$ \\
\hline $\begin{array}{l}\text { MANCOVA and Follow-up } \\
t \text {-tests on Fourth-Grade LEAP } 21 \text { to } \\
\text { Examine Gains from Grades } 3 \text { to } 4\end{array}$ & $\begin{array}{l}\text { *Language } \\
\text { *Social Studies } \\
\text { *Science } \\
\text { Mathematics }\end{array}$ & \\
\hline $\begin{array}{l}\text { MANCOVA and Follow-up } \\
t \text {-tests on Fifth-Grade ITBS } \\
\text { to Examine Gains from Grades } 4 \text { to } 5\end{array}$ & *Language & $\begin{array}{l}{ }^{*} \text { Social Studies } \\
{ }^{*} \text { Reading } \\
\text { Science } \\
\text { Mathematics }\end{array}$ \\
\hline $\begin{array}{l}\text { MANCOVA and Follow-up } \\
t \text {-tests on Fifth-Grade ITBS } \\
\text { to Examine Gains from Grades } 3 \text { to } 5\end{array}$ & $\begin{array}{l}\text { *Language } \\
\text { Science }\end{array}$ & $\begin{array}{l}\text { Social Studies } \\
\text { Mathematics } \\
\text { Reading }\end{array}$ \\
\hline
\end{tabular}

Note. Subtests are listed according to magnitude of difference in performance from highest to lowest.

*Statistically significant differences between group performance.

conduct the statistical analyses to answer research question 4. Even when Grade 3 differences were accounted for, Grade 4 LEAP 21 scores were significantly higher for FL students in all areas except mathematics, although the difference in mathematics performance favored FL students.

Research Questions 3, 5, and 6. Research questions 3, 5, and 6 examined student academic performance on the Grade 5 ITBS. For each research question, language performance on the part of the FL students significantly surpassed that of the non-FL students.

Research question 3 used a MANOVA procedure and follow-up ANOVAs to examine differences between the academic performance of nonFL and FL students on the Grade 5 reading, language, mathematics, social studies, and science subtests of the ITBS. The treatment group significantly outperformed the control group on the language subtest. However, the control group significantly outperformed the treatment group on the social studies subtest.

Research question 5 used a MANCOVA procedure and follow-up $t$-tests on the adjusted means to examine differences in academic performance on the Grade 5 reading, language, mathematics, social studies, and science ITBS scores of non-FL and FL students after 3 years of FL study. The MANCOVA procedure accounted for differences in student performance by controlling for Grade 4 LEAP 21 English language arts, mathematics, science, and social studies subtests.

When taking into account students' Grade 4 differences in LEAP 21 performance, the results were consistent with those yielded from investigating research question 3 . That is to say, language scores significantly favored the treatment group. Social studies scores, however, significantly favored the control group. Research question 5 also revealed that reading scores significantly favored the control group.

Research question 6 used a MANCOVA procedure and follow-up $t$-tests on the adjusted means to examine differences in academic performance on the Grade 5 reading, language, mathematics, social studies, and science ITBS scores of non-FL and FL students after 3 years of FL study. The MANCOVA procedure accounted for differences in student performance by controlling for Grade 
3 reading, language, mathematics, social studies, and science ITBS scores. As evidenced when using the criterion-referenced Grade 4 LEAP 21 test scores as covariates, using Grade 3 ITBS scores as covariates also yielded differences in language performance significantly favoring the treatment group. The small differences found in the Grade 3 science ITBS scores favoring the control group were no longer significant by Grade 5. Language performance remained consistently significantly greater in favor of the treatment group.

\section{Implications for Educational Policy Makers and Elementary School Administrators}

When examining student performance on the Grade 4 LEAP 21 test, FL students significantly outperformed their monolingual peers on every subtest. Students who do not pass the English language arts and mathematics subtests of the Grade 4 LEAP 21 are required to repeat Grade 4 if they are still unable to pass those subtests after taking part in summer remediation classes and retesting at the conclusion of summer school. The present study found that a greater percentage of FL students passed each LEAP 21 subtest than did non-FL students. Eight percent more FL students passed the English language arts subtest than did non-FL students. Similarly, 5\% more FL students passed the mathematics portion than did non-FL students. Although science and social studies performance is not a gatekeeper to grade level promotion, it is noteworthy to relate that FL students' pass rates were higher than their non-FL counterparts by $7 \%$ on the science subtest and by $4 \%$ on the social studies subtest.

Beyond affecting student grade promotion, student performance on the LEAP 21 factors into the Louisiana School Accountability Program. Elementary School Performance Scores are calculated for each school using students' LEAP 21 English language arts, mathematics, science, and social studies scores as well as students' composite ITBS scores, in addition to factoring in school attendance. The weighting of these components is as follows: LEAP 21 performance, $60 \%$; ITBS performance, $30 \%$; and school attendance, $10 \%$. Schools that fail to meet their growth targets are placed into corrective action and receive support to assist them in improving their performance. However, schools that meet or exceed growth targets receive financial rewards and positive growth labels. The findings of the present research indicating that FL students academically outperformed non-FL students and were more successful at passing the LEAP 21 test give credence to the notion that school administrators should look to FL programs as a means of enhancing school performance scores.

With regard to performance on the language portion of the ITBS, the treatment group scored higher than the control group in Grade 3 and significantly did so in Grade 5. Even when participants' prior standardized test scores were used as covariates, the treatment group still outperformed its control group counterpart. Thus, in addition to contributing to LEAP 21 language performance, FL study contributes to ITBS language performance as well.

The findings of the present study support the notion that sustained FL study should be provided over multiple years. After 1 year of FL instruction, there was no significant difference in students' ITBS scores, with the exception of science, which favored the non-FL students. However, after being enrolled in FL study for multiple years, the FL students significantly outperformed their nonFL counterparts. These findings underscore the positive effect that sustained FL study has on student academic achievement. Therefore, FL study should begin in the early grades and continue in an uninterrupted sequence throughout the elementary school years.

It should be noted that even when significant differences in LEAP 21 and ITBS performance between FL and non-FL student participants in the present study were not detected, the FL students still lost nothing academically and yet gained the ability to understand and use French or Spanish. Beyond working toward second language acquisition, these students have benefited from learning about the cultures and perspectives of francophone and hispanophone peoples. Moreover, they have had an opportunity to examine their own beliefs and explore their own opinions from the perspective of knowing about other cultures.

Perhaps the lack of support for FL programs on the part of school administrators is due in part to their lack of knowledge about the benefits of FL programs. Research on the effect of FL study on academic achievement can help broaden the knowledge base of school policy makers as well as educational administrators and assist them with making informed decisions regarding FL programs in elementary school systems. Moreover, as FL contributes to student achievement and has been deemed a core content area according to NCLB federal educational legislation, educational policy makers should strongly consider allocating sufficient funding to incorporate FL into statewide accountability programs along curricular areas presently tested. 


\section{Limitations of the Study}

The present study suggests that Louisiana students participating in FL study beginning in Grade 3 outperform their non-FL peers in all LEAP 21 subtests. Although these results cannot be officially generalized beyond this population, it is appropriate to state that the results on highstakes tests in other states based on state content standards linked to national content standards might yield similar results.

The present research also found that Louisiana students participating in FL study beginning in Grade 3 extending until at least Grade 5 outperformed their non-FL peers on the language portion of Grade 3 and Grade 5 ITBS. Generalization to a national population or a population of students in other states may be questionable, given possible differences between Louisiana students and other students. However, studies of similar FL programs using the ITBS as a dependent variable would be directly comparable to the results found here.

\section{Future Research Suggestions}

The primary suggestion for future research is to build on the present study by replicating it in the future to examine Grade 7 and Grade 9 Iowa Tests of Educational Development scores as well as the Grade 8 LEAP 21 scores of the students involved in the present study. This would allow for the examination of an even greater longitudinally cumulative effect of FL study, revealing whether the effects found in the present study are maintained. This design would necessitate that students comprising the treatment group of the present study continue their FL study through Grade 9. Unfortunately, it is unlikely that all school systems servicing these students have articulated FL programs commencing at the elementary level and continuing into middle/junior high school through the high school level.

In addition, studies probing the attitudes of school administrators to determine their views of the contributions of FL study to student achievement could be a useful means by which to gauge administrators' desire to include FL programs in the instructional day or their willingness to offer greater support to existing programs. Administrators should be made aware of the potential benefits FL study affords elementary students, as this would assist them in making informed decisions about the extent to which they include FL in school curricula.

\section{CONCLUSIONS}

The primary goal of the present research was to investigate the relationship between elementary school FL study and academic achievement. Several important findings of this study emerged. First, and most strikingly, FL students significantly outperformed their non-FL peers on every test (English language arts, mathematics, science, and social studies) of the Grade 4 LEAP 21. At a time when school accountability programs are the driving force behind decisions made about school curriculum and about highstakes outcomes such as grade level promotion, it is important to have a broader understanding of how FL study can contribute to student performance on state-developed standardized test measures. Second, the present research suggested that regardless of the test, whether the Grade 4 LEAP 21 or the Grade 5 ITBS, at each grade level the FL students significantly outperformed their non-FL counterparts on tests of language achievement.

A third notable finding is that the FL students in the present study significantly outperformed their monolingual peers after sustained enrollment in the Louisiana Elementary Foreign Language Program. These findings underscore the positive effect that continued FL study has on academic achievement and helps substantiate the view that FL study should commence during the early elementary grades and continue in an uninterrupted sequence throughout the course of elementary study.

The findings of the present study go beyond supporting the 1984 Louisiana BESE mandate to offer elementary FL study to children in Grades 4 through 8. A fortiori, these findings promote the view that participation in FL study should be a required component of the elementary curriculum. Further, the present research supports the assertion that the BESE FL mandate extend to include the lower elementary grades as well. Finally, policies diminishing children's access to FL study should be reconsidered based on the findings of this and other studies indicating that FL study promotes academic achievement.

\section{REFERENCES}

Armstrong, P., \& Rogers, D. (1997). Basic skills revisited: The effects of foreign language instruction on reading, math, and language arts. Learning Languages, 2, 20-31. 
Cohen, J. (1977). Statistical power analysis for the behavioral sciences. New York: Academic Press.

Davis, K. (2003). Multiple analysis of variance (MANOVA) or multiple analysis of covariance (MANCOVA). Unpublished manuscript, Louisiana State University.

DiPietro, R. (1980). Filling the elementary curriculum with languages: What are the effects? Foreign Language Annals, 13, 115-123.

Gall, D., Borg, W., \& Gall, J. (1996). Educational research: An introduction (6th ed.). White Plains, NY: Longman.

Garfinkel, A., \& Tabor, K. (1991). Elementary school foreign languages and English reading achievement: A new view of the relationship. Foreign Language Annals, 24, 375-382.

Hakuta, K. (1990). Language and cognition in bilingual children. In A. Padilla, C. Valdez, \& H. Fairchild (Eds.), Bilingual education: Issues and strategies (pp. 47-59). Newbury Park, CA: Sage.

The Iowa Tests of Basic Skills. (2001). Rolling Meadows, IL: Riverside.

Johnson, C., Ellison, F., \& Flores, J. (1961). The effect of foreign language instruction on basic learning in elementary schools. Modern Language Journal, 45, 200-202.

Johnson, C., Flores, J., \& Ellison F. (1963). The effect of foreign language instruction on basic learning in elementary schools: A second report. Modern Language Journal, 47, 8-11.

Landry, R. (1973). The enhancement of figural creativity through second language learning at the elementary level. Foreign Language Annals, 7, 111115 .
Landry, R. (1974). A comparison of second language learners and monolinguals on divergent thinking tasks at the elementary school level. Modern Language Journal, 58, 10-15.

Lang, M. (1990). Elementary grade-level foreign language studies and student performance on reading and language arts tests: A study of relationship by the Bureau of Pupil Accountability for the Bureau of Academic Support. Baton Rouge: Louisiana Department of Education.

Leino, W., \& Haak, L. (1963). The teaching of Spanish in the elementary schools and the effects on achievement in other selected subject areas. St. Paul, MN: St. Paul Public Schools.

Lopato, E. (1963). FLES and academic achievement. French Review, 36, 499-507.

Louisiana Department of Education. (2001). 200001 Louisiana interpretive guide. Baton Rouge: Louisiana Department of Education.

Rafferty, E. (1986). Second language study and basic skills in Louisiana. Baton Rouge: Louisiana Department of Education

Saunders, C. (1998). The effect of the study of a foreign language in the elementary school on scores on the Iowa Tests of Basic Skills and an analysis of student-participant attitudes and abilities. Unpublished doctoral dissertation, University of Georgia, Athens.

Schuster, B. (2005). Did a Foreign Language in the Elementary Schools (FLES) program in a Kansas school district affect students' academic achievement in English? Foreign Language Annals, 38, 344-353.

APPENDIX

Louisiana Parishes Comprising Regional Education Service Centers

Region Parishes Served

Region 1 St. Charles, Jefferson, Orleans, St. Bernard, and Plaquemines

Region 2 Pointe Coupee, West Feliciana, East Feliciana, Iberville, St. Helena, Livingston, East Baton Rouge, West Baton Rouge, Tangipahoa, Washington, and St. Tammany

Region 3 St. Mary, Assumption, Ascension, St. James, St. John the Baptist, Terrebonne, and Lafourche

Region 4 Evangeline, St. Landry, Acadia, Lafayette, St. Martin, Vermilion, and Iberia

Region 5 Cameron, Calcasieu, Jefferson Davis, Allen, and Beauregard

Region 6 Vernon, Sabine, Rapides, Avoyelles, LaSalle, Grant, Winn, and Natchitoches

Region 7 Caddo, Bossier, De Soto, Red River, Bienville, Webster, and Claiborne

Region 8 Concordia, Catahoula, Tensas, Franklin, Caldwell, Jackson, Lincoln, Ouachita, Union, Morehouse, Richland, West Carroll, East Carroll, and Madison 


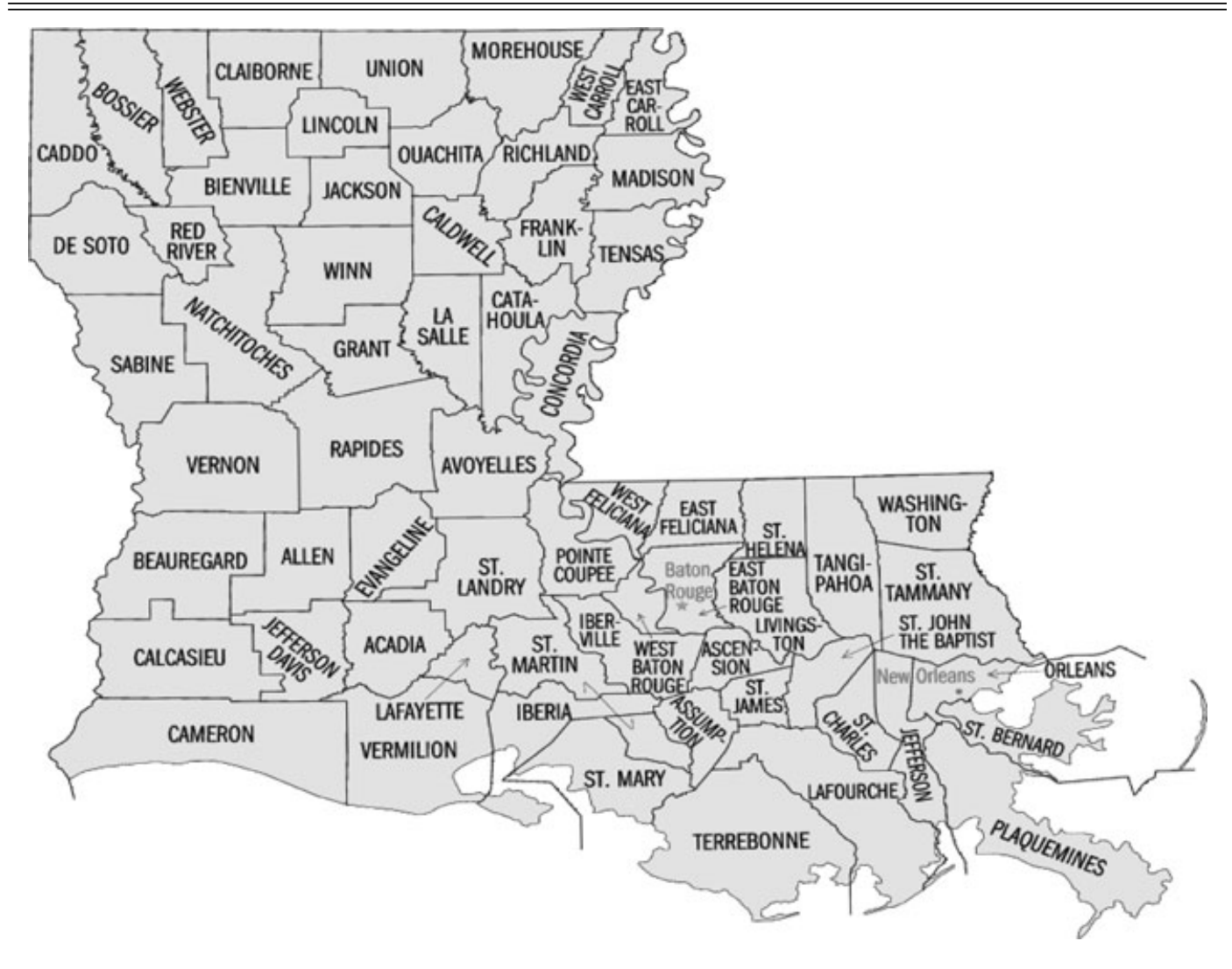

Source: http://www.doe.state.la.us/lde/offices/rsc.html

\section{Forthcoming in The Modern Language Journal, 94.2}

Ariana Mikulski. "Receptive Volitional Subjunctive Abilities in Heritage and Traditional FL Learners of Spanish."

Yasuhiro Imai. "Emotions in SLA: New Insights from Collaborative Learning for an EFL Classroom."

Melinda Martin-Beltrán. "The Two-Way Language Bridge: Co-Constructing Bilingual Language Learning Opportunities."

Trude Heift. "Prompting in CALL: A Longitudinal Study of Learner Uptake."

Eton Churchill, Takako Nishino, Hanako Okada, \& Dwight Atkinson. "Symbiotic Gesture and the Sociocognitive Visibility of Grammar in Second Language Acquisition."

Marianna Pankova. "Towards Mastering the Discourses of Reasoning: Use of Grammatical Metaphor at Advanced Levels of FL Acquisition." 